\title{
Widespread dissemination of class 1 integron components in soils and related ecosystems as revealed by cultivation-independent analysis
}

\author{
Sven Jechalke ${ }^{1}$, Susanne Schreiter ${ }^{1}$, Birgit Wolters ${ }^{1,2}$, Simone Dealtry ${ }^{1}$, Holger Heuer ${ }^{1}$ and \\ Kornelia Smalla ${ }^{1 *}$
}

${ }^{1}$ Institute for Epidemiology and Pathogen Diagnostics, Julius Kühn-Institut, Federal Research Centre for Cultivated Plants (JKI), Braunschweig, Germany

2 Institute of Environmental and Sustainable Chemistry, Technische Universität Braunschweig, Braunschweig, Germany

\author{
Edited by: \\ Mark Montforts, National Institute \\ for Public Health and the \\ Environment, Netherlands \\ Reviewed by: \\ Atte Von Wright, University of \\ Eastern Finland, Finland \\ Teresa M. Coque, Hospital \\ Universitario Ramón y Cajal, Spain \\ *Correspondence: \\ Kornelia Smalla, Institute for \\ Epidemiology and Pathogen \\ Diagnostics, Julius Kühn-Institut, \\ Messeweg 11-12, 38104 \\ Braunschweig, Germany \\ e-mail: kornelia.smalla@jki.bund.de
}

Class 1 integrons contribute to the emerging problem of antibiotic resistance in human medicine by acquisition, exchange, and expression of resistance genes embedded within gene cassettes. Besides the clinical setting they were recently reported from environmental habitats and often located on plasmids and transposons, facilitating their transfer and spread within bacterial communities. In this study we aimed to provide insights into the occurrence of genes typically associated with the class 1 integrons in previously not studied environments with or without human impact and their association with IncP-1 plasmids. Total community DNA was extracted from manure-treated and untreated soils, lettuce and potato rhizosphere, digestates, and an on-farm biopurification system and screened by PCR with subsequent Southern blot hybridization for the presence of the class 1 integrase gene int/1 as well as qacE and qacE 1 resistance genes. The results revealed a widespread dissemination of class 1 integrons in the environments analyzed, mainly related to the presence of qacE $\Delta 1$ genes. All 28 IncP- $1 \varepsilon$ plasmids carrying class 1 integrons, which were captured exogenously in a recent study from piggery manure and soils treated with manure, carried qacE 1 genes. Based on the strong hybridization signals in the rhizosphere of lettuce compared to the potato rhizosphere, the abundances of int/1, qacE/qacE $\Delta$ 1, and sul1 genes were quantified relative to the 16S rRNA gene abundance by real-time PCR in the rhizosphere of lettuce planted in three different soils and in the corresponding bulk soil. A significant enrichment of int/1 and qacE/qacE 1 genes was confirmed in the rhizosphere of lettuce compared to bulk soil. Additionally, the relative abundance of korB genes specific for IncP-1 plasmids was enriched in the rhizosphere and correlated to the int/1 gene abundance indicating that IncP-1 plasmids might have contributed to the spread of class 1 integrons in the analyzed soils.

Keywords: intl1, sul1, qacE 1 , qacE, IncP-1 korB, digestates, manured soil and rhizosphere, biofilter

\section{INTRODUCTION}

Class 1 integrons are bacterial genetic elements that are widely distributed in the clinical setting as well as in the environment, where they are able to acquire, exchange, and express genes embedded in gene cassettes (Mazel, 2006; Gillings et al., 2008; Heuer and Smalla, 2012; Jaglic and Cervinkova, 2012; Stalder et al., 2012; Zhao et al., 2012; Stalder et al., 2013). These gene cassettes can contain resistance genes for almost all antibiotic families including beta-lactams, aminoglycosides, trimethoprim, chloramphenicol, fosfomycin, macrolides, lincosamides, rifampicin, and quinolones (Stalder et al., 2012). Furthermore, class 1 integrons are often located on plasmids, transposons, and flanked by insertion sequences which facilitate their transfer and spread within bacterial communities and to bacterial pathogens, which contributes to the worldwide crisis in the management of bacterial infections (Gillings et al., 2008).
Besides the selection and dissemination of class 1 integrons by antibiotics, selective pressure by heavy metals or quaternary ammonium compounds (QACs) has also been shown to be a factor involved in their dissemination since qac genes encoding resistance determinants to QACs are commonly found on class 1 integrons (Stalder et al., 2012). QACs are biocides which are widely distributed and applied in hospitals, industry, and cosmetics (Buffet-Bataillon et al., 2012). In the food processing industry QACs are by far the most commonly used disinfectant due to their biocidal performance as well as their non-tainting, non-toxic, and non-corrosive properties (Holah et al., 2002). Their antimicrobial activity is mainly based on interactions with phospholipids and proteins of bacterial membranes leading to the disruption of membrane integrity and leakage of cellular content (Gilbert and Moore, 2005; Ioannou et al., 2007). Resistance against QACs is mediated by qac genes encoding proteins involved in efflux-based 
multidrug pumps with relatively low specificity. Different qac genes have been described so far (qacA, qacB, qacC, qacD, qacE, qacF, qacG, qacH, qacI, qacJ, qacK, and qacZ), which partly share a high homology (Partridge et al., 2009; Jaglic and Cervinkova, 2012).

In the recent time there is growing concern about a possible cross-resistance between antibiotics and QACs in environmental and especially in food-associated bacteria (Morente et al., 2013). The qacE gene and its attenuated variant qacE $\Delta 1$ are widely spread in Gram-negative bacteria, which is mainly due to the high prevalence of class 1 integrons associated with qacE $\Delta 1$, but may occur in Gram-positive cocci as well (Jaglic and Cervinkova, 2012). It was demonstrated for a reed bed system that QAC selection was linked to an increase in class 1 integron incidence in bacterial isolates and therefore has the potential to co-select for antibiotic resistance genes (Gaze et al., 2005). Furthermore, it was shown that the prevalence of class 1 integrons and qac genes in the environment exposed to detergents and/or antibiotic residues was increased (Gaze et al., 2011).

Class 1 integrons have been frequently found on IncP-1 plasmids, which are broad host range plasmids with a wide distribution in the environment (Popowska and Krawczyk-Balska,

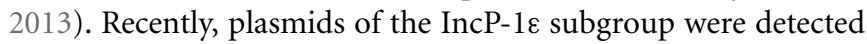
in manure and arable soil and the isolation and characterization of 50 IncP- $1 \varepsilon$ plasmids revealed that all carried class 1 integrons with highly varying sizes of the gene cassette region and sull genes conferring resistance against sulfonamides, indicating their important role as vectors for horizontal transfer of antibiotic resistance in agricultural systems (Heuer et al., 2012). However, the knowledge on the distribution of qacE and qacE $\Delta 1$ genes on IncP- $1 \varepsilon$ plasmids and their role in the distribution of QAC resistance and potential co-selection of antibiotic resistance in the environment was poor.

In this study, we aimed to provide insights into the occurrence of sequences typically associated with the clinically relevant class 1 integrons in different and previously not analyzed environments to assess the potential for a co-selection of antibiotic resistance and associated risks for human health. Therefore, total community DNA from different soils, digestates, and an onfarm biopurification system was extracted and screened by PCR with subsequent Southern blot hybridization for the presence and abundance of the class 1 integrase gene intI1 as well as qacE and qacE $\Delta 1$ resistance genes. Additionally, quantitative real-time PCR (qPCR) was used to compare the abundance of class 1 integron associated genes intI1, qacE/qacE $\Delta 1$, and sull with the abundance of $k o r B$ and $\operatorname{trf} A \varepsilon$ genes specific for IncP-1 and IncP-1 $1 \varepsilon$ plasmids, respectively.

\section{MATERIALS AND METHODS ORIGIN OF ENVIRONMENTAL SAMPLES AND CAPTURED PLASMIDS}

Bulk soil and rhizosphere from lettuce and potato were sampled from field plots in Grossbeeren, south of Berlin, Germany, described by Rühlmann (2006), which had received mineral fertilizer only for more than 10 years. The three soil types were characterized as Arenic-Luvisol with less silty sand and 5.5\% clay (diluvial sand, DS), Gleyic-Fluvisol with heavy sandy loam and $27.5 \%$ clay (alluvial loam, AL), and Luvic-Phaeozem with medium clayey silt and $17.2 \%$ clay (loess loam, LL) (Rühlmann and Ruppel, 2005).

In addition, arable soil samples amended with manure containing sulfadiazine or difloxacin or no antibiotics were taken from a field plot near Jülich, Germany, as described previously (Jechalke et al., 2013b,c).

Samples from a pesticide-degrading biofilter operated on a farm near Kortrijk, Belgium, were collected as described by Jechalke et al. (2013a). The samples were collected three times over a season before start-up (March), during processing (July), and after closedown (September).

Digestates were sampled from four different biogas plants (BGP) in Germany. From each BGP $14 \mathrm{ml}$ digestate was centrifuged for $10 \mathrm{~min}(3,100 \times g)$ and the pellet was homogenized.

The 28 IncP- $1 \varepsilon$ plasmids further characterized here originated from a study by Heuer and colleagues and were exogenously captured in Escherichia coli CV601gfp from bacterial communities of manure and manured soil (Heuer et al., 2012).

\section{EXTRACTION OF TOTAL COMMUNITY DNA}

Total community (TC-) DNA was extracted from $0.5 \mathrm{~g}$ of soil, biofilter sample, or $0.1 \mathrm{~g}$ homogenized digestate pellet using the FastDNA ${ }^{\circledR}$ Spin Kit for soil (MP Biomedicals, Heidelberg, Germany). The extracted DNA from soil and biofilter samples was purified by the GeneClean ${ }^{\circledR}$ Spin Kit (MP Biomedicals), following the instructions of the manufacturer. The DNA from the digestates was diluted 1:5 in $10 \mathrm{mM}$ Tris/ $\mathrm{HCl}(\mathrm{pH}$ 8.0) with $1 \mathrm{mM}$ EDTA.

To obtain a rhizosphere pellet from the lettuce and potato plants of the Grossbeeren field site, first the loosely attached soil from three plants per replicate was removed by shaking and subsequent root washing in sterile water. Afterwards $5 \mathrm{~g}$ roots were suspended in $15 \mathrm{ml}$ sterile $0.3 \% \mathrm{NaCl}$ three times and treated in a Stomacher 400 Circulator (Seward, Worthing, West Sussex, UK) for $30 \mathrm{~s}$ at high speed. The supernatants were centrifuged (2 min, $500 \times g)$ and the pellet was added to the root sample together with $15 \mathrm{ml}$ sterile $0.3 \% \mathrm{NaCl}$ for the second and third Stomacher treatment. The three supernatants were combined and centrifuged at $10,000 \times g$ for 30 min to obtain the microbial pellet. The pellet was resuspended and transferred to a $2 \mathrm{ml}$ reaction tube and centrifuged at $14,000 \times g$ for $20 \mathrm{~min}$. The resulting pellets were used for the TC-DNA extraction as described above.

\section{PCR WITH SUBSEOUENT SOUTHERN BLOT HYBRIDIZATION}

The occurrence of intI1, qacE, and qacE $\Delta 1$ genes in TC-DNA was analyzed by PCR amplification and subsequent Southern blot hybridization. Primers used for the amplification of the intI1 gene (IntI1F, IntI1R) were described by Moura et al. (2007). Primers for the amplification of qacE $(\mathrm{F} 1, \mathrm{R} 2)$ and qacE $\Delta 1$ (qacE $\Delta 1$ $\mathrm{F}$, qacE $\Delta 1 \mathrm{~B})$ were used as described previously, but the qacE primer R2 was modified (TTAGTGGGCACTTGCTTTGGAAAG) to increase its specificity (Sandvang et al., 1997; Kazama et al., 1998). Digoxigenin labeled probes were generated from PCR products as described by Jechalke et al. (2013b) using plasmids $\mathrm{R} 751$ and $\mathrm{pB} 10$ as templates for $q a c E$ and $q a c E \Delta 1$, respectively, and plasmids 1-23, 3-408, 3-414, and pKJK5 for intI1. 
Southern blotting and hybridization of PCR products were done as described by Sambrook et al. (1989). Ten $\mu$ l PCR products were run on $1 \%$ agarose gels for intI1, qacE, and qacE $\Delta 1$. The gels were Southern blotted to a Hybond-N membrane (GE Healthcare Limited, Amersham, UK) using standard protocols (Sambrook et al., 1989). It has to be mentioned that in case the sample only contains the qacE gene, the detection of $q a c E \Delta 1$ would give a positive result, too, since the primers for $q a c E \Delta 1$ are complementary to a region also present in the qacE gene.

\section{QUANTIFICATION OF TARGET GENES}

The class 1 integron integrase gene intI1 was quantified by quantitative real-time PCR $5^{\prime}$-nuclease assays in a CFX96 real-time PCR detection system (Bio-Rad, Hercules, CA) as described previously (Barraud et al., 2010). The quaternary ammonium compound resistance genes qacE and the qacE $\Delta 1$ variant were quantified with the primers qacEallF (CGCATTTTATTTTCT TTCTCTGGTT) and qacEallR (CCCGACCAGACTGCATAAGC) and the probe qacEallP (FAM-TGAAATCCATCCCTGTCGG TGT-TAMRA), developed in the present study, with $10 \mathrm{~min}$ at $95^{\circ} \mathrm{C}$ and 40 cycles of $30 \mathrm{~s}$ at $95^{\circ} \mathrm{C}$ and $60 \mathrm{~s}$ at $60^{\circ} \mathrm{C}$. Standard dilutions were generated from a cloned $226 \mathrm{bp}$ PCR product of the plasmid pKJK5 using primers (qacE $\Delta 1 \mathrm{~F}$, qacE $\Delta 1 \mathrm{~B}$ ) described by Sandvang et al. (1997). To assess the contribution of IncP-1 plasmids and in particular of the IncP- $1 \varepsilon$ subgroup, the abundance of kor $B$ genes specific for IncP-1 plasmids of all known subgroups and the abundance of $\operatorname{trf} A$ genes specific for the IncP-1E subgroup were determined relative to $16 \mathrm{~S}$ rRNA gene copies $(\mathrm{rrn})$ as described by Heuer et al. (2012) and Jechalke et al. (2013a).

The 16S rRNA genes were quantified using the primers BACT1369F and PROK1492R and the probe TM1389F (Suzuki et al., 2000). Differences in bacterial DNA and amplification efficiency between samples were adjusted by dividing the target numbers of the respective genes by the rrn gene copy numbers and the log transformation of the results (relative abundance).

The correlation between the relative abundance of intI1 and the class 1 associated genes qacE/qacE $\Delta 1$ and sull as well as the relative abundance of korB was tested by linear regression analysis $(p<0.05$; SAS 9.3; SAS Institute Inc., Cary, NC).

\section{RESULTS}

\section{GENE DETECTION AND QUANTIFICATION IN ENVIRONMENTAL SAMPLES}

PCR with subsequent Southern blot hybridization revealed that all tested TC-DNAs extracted from manure-treated soil, lettuce and potato rhizosphere, digestates, and biofilter samples contained intIl genes and the qacE $\Delta 1$ gene variant but at very different abundances as indicated by the hybridization signal intensity (Table 1, Figures S1-S3). The qacE gene was found in a lower frequency and was observed only in the biofilter samples (Table 1), in the rhizosphere of lettuce grown in DS soil, and in one replicate of potato rhizosphere from LL soil (Table 1). As the hybridization signals were strongly increased in the TC-DNA from lettuce rhizosphere compared to potato rhizosphere, PCR amplifications from lettuce rhizosphere and the corresponding bulk soil were repeated and the hybridization signals indicated an enrichment of populations carrying intI 1 and qacE $\Delta 1$ in the
Table 1 | Detection of class 1 integron integrase genes (int/1) and quaternary ammonium compound resistance genes qacE and qacE 1 by PCR and subsequent Southern blot hybridization.

\begin{tabular}{|c|c|c|c|c|}
\hline Sample type & & IntI1 & qacE & $\operatorname{qacE} \Delta 1^{\mathrm{a}}$ \\
\hline \multirow[t]{4}{*}{ Biogas plant } & $\begin{array}{l}\text { Digestate } \\
\text { (BGA1) }\end{array}$ & +++ & - & ++ \\
\hline & $\begin{array}{l}\text { Digestate } \\
\text { (BGA2) }\end{array}$ & +++ & - & ++ \\
\hline & $\begin{array}{l}\text { Digestate } \\
\text { (BGA7) }\end{array}$ & +++ & - & ++ \\
\hline & $\begin{array}{l}\text { Digestate } \\
\text { (BGA9) }\end{array}$ & +++ & - & ++ \\
\hline \multirow[t]{4}{*}{$\begin{array}{l}\text { Bulk soil } \\
\text { Merzenhausen }\end{array}$} & $\begin{array}{l}\text { Manure } \\
\text { +difloxacin }\end{array}$ & ++ & - & ++ \\
\hline & Manure & ++ & - & ++ \\
\hline & $\begin{array}{l}\text { Manure } \\
\text { +sulfadiazine }\end{array}$ & ++ & - & ++ \\
\hline & Manure & ++ & - & ++ \\
\hline \multirow[t]{3}{*}{ Biofilter Kortrijk } & $\begin{array}{l}\text { Before startup } \\
\text { (March) }\end{array}$ & +++ & + & ++ \\
\hline & $\begin{array}{l}\text { During } \\
\text { processing } \\
\text { (July) }\end{array}$ & +++ & ++ & ++ \\
\hline & $\begin{array}{l}\text { After } \\
\text { closedown } \\
\text { (September) }\end{array}$ & +++ & ++ & ++ \\
\hline \multirow{3}{*}{$\begin{array}{l}\text { Lettuce } \\
\text { rhizosphere }^{b}\end{array}$} & DS soil & +++ & + & ++ \\
\hline & AL soil & +++ & - & ++ \\
\hline & LL soil & +++ & - & ++ \\
\hline \multirow{12}{*}{$\begin{array}{l}\text { Potato } \\
\text { rhizosphere }^{b}\end{array}$} & DS soil (1) & +++ & - & ++ \\
\hline & DS soil (2) & ++ & - & + \\
\hline & DS soil (3) & + & - & + \\
\hline & DS soil (4) & ++ & - & + \\
\hline & AL soil (1) & + & - & + \\
\hline & AL soil (2) & + & - & + \\
\hline & AL soil (3) & ++ & - & + \\
\hline & AL soil (4) & + & - & + \\
\hline & LL soil (1) & ++ & - & + \\
\hline & LL soil (2) & + & - & + \\
\hline & LL soil (3) & + & + & + \\
\hline & LL soil (4) & + & - & + \\
\hline
\end{tabular}

Total community DNA used as template was extracted from digestates of four different biogas plants, from soil of an agricultural field located near Merzenhausen, Germany, from a biofilter near Kortrijk, Belgium, for the remediation of pesticide contaminated water, as well as from lettuce and potato rhizosphere from field plots located in Grossbeeren, Germany. Different intensities in fluorescence are indicated $(+,++,+++)$.

a In case the sample only contains qacE the detection of qacE $\Delta 1$ would also give a positive result since the primers and probe for qacE 1 are complementary to a region also present in the qacE gene.

${ }^{b}$ Diluvial sand (DS), alluvial loam (AL), and loess loam (LL). 
rhizosphere of lettuce grown in all three soil types (Figures S4, S5). This result was confirmed by quantifying the class 1 integron integrase genes intI 1 and quaternary ammonium compound resistance genes $q a c E / q a c E \Delta 1$ by qPCR. In accordance with the results from Southern blot hybridization, all samples contained intI1 and qacE/qacE $\Delta 1$ genes (Figure 1). The abundances of intI1 and $q a c E / q a c E \Delta 1$ relative to $16 \mathrm{~S}$ rRNA genes were significantly higher in the rhizosphere than in bulk soil ( $t$-test, $p<0.05$ ). The relative abundance of sull was not significantly different between bulk soil and rhizosphere ( $t$-test, $p<0.05)$. The relative abundance of intI1, qacE/qacE $\Delta 1$, and sull was not significantly different among the different soil types in bulk soil or rhizosphere, only in the rhizosphere of DS soil the relative abundance of sull was lower (Tukey test, $p<0.05$ ). Linear regression analysis revealed a significant correlation between the relative abundances of intI1 and $q a c E / q a c E \Delta 1\left(p=0.0003, R^{2}=0.46\right)$ but not between intI1 and $\operatorname{sul} 1\left(p=0.63, R^{2}=0.01\right)$.

To assess a possible link between IncP-1 plasmids and the prevalence of class 1 integrons and associated genes, the abundance of korB genes specific for IncP-1 plasmids of all known subgroups was determined relative to $16 \mathrm{~S}$ rRNA genes. In $\mathrm{AL}$ and LL bulk soil, the relative abundance of $\operatorname{korB}$ was below the detection limit $(-4.6)$ of the qPCR assay. In the DS bulk soil the relative abundance of $k o r B$ was not significantly different from the abundance of intI1, qacE/qacE $\Delta 1$, and sull (Tukey test, $p<0.05)$. In the $\mathrm{AL}$ rhizosphere, the relative abundance of $\operatorname{kor} B$ was significantly higher than the relative abundance of intI1, qacE/qacE $\Delta 1$, and sul1 (Figure 1). In the rhizosphere of LL soil, the relative abundance of $k o r B$ was higher than the relative abundances of intI1 and sull but not significantly higher than the relative abundance of $q a c E / q a c E \Delta 1$. In the rhizosphere of DS soil, the relative abundance of $k o r B$ was higher than the relative abundances of qacE/qacE $\Delta 1$ and sull but not significantly higher than intI1 of class 1 integrons. Overall, in the rhizosphere

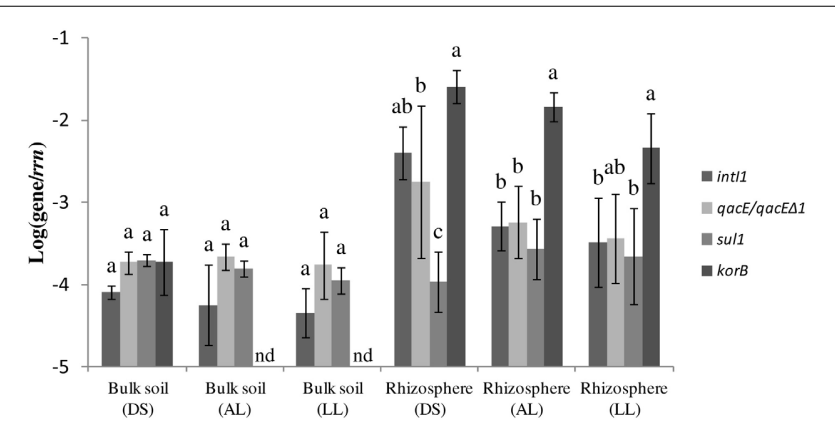

FIGURE 1 | Abundance of class 1 integron integrase gene intl1, quaternary ammonium compound resistance genes qacE/qacE 1 , sulfonamide resistance gene sul1, and korB genes related to IncP-1 plasmids relative to $16 \mathrm{~S}$ rRNA gene copies (rrn). Results are shown for bulk soil and rhizosphere of lettuce for the three soil types: alluvial loam $(A L)$, diluvial sand (DS), and loess loam (LL). Error bars represent standard deviations of $n=4$ replicates or of $n=3$ replicates for bulk soil (DS). Values below detection limit (-4.6) of the qPCR assay for korB are indicated (nd). Pairwise comparisons were made for each soil type of bulk soil and rhizosphere separately. Differing letters indicate significant differences between relative abundances of target genes (Tukey test, $p<0.05$ ). the relative abundance of the korB gene was higher than in DS bulk soil (Figure 1, $t$-test, $p<0.05$ ). Linear regression analysis revealed a significant correlation between the relative abundance of intI1 and $\operatorname{korB}\left(p=0.0012, R^{2}=0.57\right)$. Additionally, the relative abundance of the $\operatorname{trf} A$ genes specific for the IncP-1 $\varepsilon$ subgroup was determined. Only in two replicates of LL rhizosphere a value clearly above the detection limit $(-4.6)$ of the qPCR assay could be detected (data not shown).

\section{DETECTION OF qacE AND qacE 1 ON EXOGENOUSLY ISOLATED IncP-1 $\varepsilon$ PLASMIDS}

IncP- $1 \varepsilon$ plasmids which were previously captured by exogenous plasmid isolation from different environments were tested for the presence of class 1 integron integrase genes intI1 and quaternary ammonium compound resistance genes qacE and qacE $\Delta 1$ by PCR and subsequent Southern blot hybridization. All IncP-1 $1 \varepsilon$ plasmids carried intI1 and qacE $\Delta 1$ while qacE was not detected (Table 2). No difference in the presence of intI1 and qacE/qacE $\Delta 1$ was observed between plasmids captured from different environmental compartments such as soil and manure and between the experiments.

\section{DISCUSSION}

The class 1 integron integrase gene intI1 and quaternary ammonium compound resistance gene qacE $\Delta 1$ were detected by PCRSouthern blot hybridization in all samples of manure-treated arable bulk soil as well as in lettuce and potato rhizosphere, digestates of biogas plants, and biofilter material (Table 1), although at very different abundance. Consequently, the present study expands the environmental settings in which class 1 integrons were detected and the findings are in line with the previously reported dissemination of these genes in natural environments and environments with anthropogenic impact (Gillings et al., 2008; Gaze et al., 2011). In contrast to qacE $\Delta 1$, the gene qacE was only detected by PCR-Southern blot hybridization in the samples from a biofilter used to degrade pesticides as well as in one replicate of potato rhizosphere of LL soil and in lettuce rhizosphere of DS soil, indicating a lower distribution of this gene variant in the environment. A low abundance of qacE was also observed by Chuanchuen et al. (2007) who could detect qacE $\Delta 1$ but not qacE genes in Salmonella enterica isolates from poultry and swine as well as by Farkas et al. (2013) who could detect qacE $\Delta 1$ but not qacE genes in biofilm samples collected at a drinking water treatment plant facility. Furthermore, in clinical isolates of Gram-negative bacteria qacE $\Delta 1$ was found in $10 \%$ of the isolates $(n=103)$ while qacE was only found in one P. aeruginosa strain (Kücken et al., 2000). Kazama and colleagues studied the presence of $q a c E$ and $q a c E \Delta 1$ in clinical and environmental isolates from Japan. While qacE $\Delta 1$ was detected frequently in isolates from the clinic and the environment, qacE could be only detected in clinical isolates of $P$. aeruginosa (Kazama et al., 1998).

Interestingly, the initial PCR-Southern blot hybridization based screening indicated that the intI1 and the qacE $\Delta 1$ genes were strongly enriched in the lettuce rhizosphere compared to potato rhizosphere samples. This finding is in accordance with the plant species dependent bacterial community composition in the rhizosphere (Berg and Smalla, 2009). Quantitative real-time PCR 


\begin{tabular}{|c|c|c|c|c|}
\hline Plasmid & Source & IntI1 & qacE & qacE $\Delta 1$ \\
\hline $2-S 2$ & Manure & + & - & + \\
\hline $2-S 5$ & Manure & + & - & + \\
\hline $3-S 1$ & Manure & + & - & + \\
\hline $6-S 1$ & Manure & + & - & + \\
\hline $9-\mathrm{T} 4$ & Manure & + & - & + \\
\hline $1-83$ & Soil microcosm & + & - & + \\
\hline $1-91$ & Soil microcosm & + & - & + \\
\hline $1-111$ & Soil microcosm & + & - & + \\
\hline $1-115$ & Soil microcosm & + & - & + \\
\hline $1-127$ & Soil microcosm & + & - & + \\
\hline $1-131$ & Soil microcosm & + & - & + \\
\hline $1-135$ & Soil microcosm & + & - & + \\
\hline $1-146$ & Soil microcosm & + & - & + \\
\hline $1-163$ & Soil microcosm & + & - & + \\
\hline $1-167$ & Soil microcosm & + & - & + \\
\hline $2-238$ & Soil microcosm & + & - & + \\
\hline $3-407$ & Soil microcosm & + & - & + \\
\hline $3-409$ & Soil microcosm & + & - & + \\
\hline $3-420$ & Soil microcosm & + & - & + \\
\hline $3-427$ & Soil microcosm & + & - & + \\
\hline $3-428$ & Soil microcosm & + & - & + \\
\hline C 131 & Soil mesocosm & + & - & + \\
\hline 253 & Field soil & + & - & + \\
\hline 260 & Field soil & + & - & + \\
\hline 263 & Field soil & + & - & + \\
\hline 267 & Field soil & + & - & + \\
\hline 268 & Field soil & + & - & + \\
\hline 269 & Field soil & + & - & + \\
\hline
\end{tabular}

was performed to confirm the enrichment of class 1 integrons and quaternary ammonium resistance genes qacE and qacE $\Delta 1$ in the rhizosphere of lettuce. Furthermore, sull genes were quantified, which are typically associated with qacE $\Delta 1$ at the $3^{\prime}$ conserved segment, a structural organization also described for "clinical integrons" (Gillings et al., 2009; Stalder et al., 2012). In the rhizosphere samples in general, a significantly higher abundance of intI1 and qacE/qacE $\Delta 1$ but not of sul1 relative to $16 \mathrm{~S}$ rRNA genes was observed compared to the bulk soil samples, and linear regression analysis showed a correlation between intI1 and qacE/qacE $\Delta 1$ but no significant correlation between intI 1 and sull relative abundance, which may indicate an increased abundance of integron types not following the typical structural organization of clinical integrons. However, except for DS rhizosphere, the relative abundances of intI1, qacE/qacE $\Delta 1$, and sull were not significantly different within one soil type, indicating that the prevalent class 1 integrons mainly consisted of the clinically related qacE $\Delta 1-s u l 1$ type. In the rhizosphere of DS soil the relative abundance of sull genes was lower than of intI1 and qacE/qacE $\Delta 1$ genes, probably due to a higher abundance of class 1 integrons with the qacE gene located at the $3^{\prime}$ conserved segment or the presence of other class 1 integron types lacking the sull gene, as for example observed in a commensal population of bacteria from patients in an intensive care unit (Betteridge et al., 2011). In accordance with this, only in DS rhizosphere qacE was detected by PCR with subsequent Southern blot hybridization (Figure S2).

Class 1 integrons are not self-transferable elements and therefore depend on the association with mobile genetic elements such as transposons and plasmids for their dissemination among bacteria. Plasmids of the incompatibility group IncP-1 were isolated from different environments and are known to spread genes between distinct phylogenetic groups of bacteria, including genes conferring resistance against antibiotics or QACs (Schlüter et al., 2007; Heuer and Smalla, 2012; Popowska and Krawczyk-Balska, 2013). Six distinct phylogenetic clades have been described, including $\alpha, \beta, \gamma, \delta, \varepsilon$, and $\zeta$, which differ in host range (Yano et al., 2013). IncP-1 $\varepsilon$ plasmids have been found in different environments such as estuarine waters (Oliveira et al., 2012), agricultural soils (Sen et al., 2011), the influent of a Danish wastewater treatment plant (Bahl et al., 2009), and they could be frequently captured from manure and manure-treated soils (Heuer et al., 2012). Recently, Heuer et al. (2012) characterized fifty IncP-1ع plasmids exogenously captured from manure and manure-treated arable soil into an E. coli recipient. All of them carried class 1 integrons with highly varying sizes of the gene cassette region and the sull gene and therefore the authors of this study suggested that IncP-1 $\varepsilon$ plasmids might be important vectors for horizontal transfer of antibiotic resistance in agricultural systems (Heuer et al., 2012). Here, we could show that all 28 plasmids selected from these IncP- $1 \varepsilon$ plasmids contain additionally the qacE $\Delta 1$ but not the qacE gene which is in accordance to the widely observed $3^{\prime}$ conserved segment composed of qacE 1 and sul1 (Table 2). To assess the distribution and abundance of IncP-1 plasmids containing class 1 integrons in an agricultural model system, their abundance was determined by quantitative real-time PCR in the rhizosphere of lettuce and the corresponding bulk soil.

The korB genes specific for IncP-1 plasmids could be detected in all lettuce rhizosphere samples but only in the DS bulk soil the relative abundance of $\operatorname{kor} B$ was above the detection limit of the qPCR assay (Figure 1). This is reasonable because IncP1 plasmids are often scarce in soil (Heuer and Smalla, 2012). Additionally, DS soil has a high proportion of sand and gravel which probably exerted a selective pressure on the bacterial community by more intensive drying events and lower nutrient contents compared to the two other soils leading to a selective advantage of plasmid carrying populations with a higher genetic flexibility. In the rhizosphere samples, corresponding to the enrichment of class 1 integrons and qacE $\Delta 1$ resistance genes, the relative abundance of korB carrying populations was significantly higher than in DS bulk soil. This is in line with the consideration that the rhizosphere in general is a hot spot for bacterial activity and horizontal gene transfer (van Elsas et al., 2003; Heuer and Smalla, 2012), which seems to be triggered by exudation and root growth affecting the cell density, distribution and metabolic activity (Mølbak et al., 2007). Furthermore, IncP1 plasmids are known to carry catabolic genes and were shown to efficiently transfer in the rhizosphere (Pukall et al., 1996; Top 
and Springael, 2003; Mølbak et al., 2007; Heuer et al., 2012; Król et al., 2012; Popowska and Krawczyk-Balska, 2013), which might indicate that root exudates might have selected for populations carrying catabolic plasmids. This hypothesis might be supported by a significant enrichment of Variovorax populations in the rhizosphere of all three soil types (data not published), a genus which is known to be able to carry catabolic plasmids of the IncP-1 group (Kim et al., 2013). Interestingly, in the DS bulk soil the relative abundance of IncP-1 plasmids was similar to the abundance of class 1 integron associated genes intI1, qacE/qacE $\Delta 1$, and sul1 (Figure 1), which indicated that class 1 integrons with typical structural organization of clinical integrons might have been associated with IncP-1 plasmids. Furthermore, linear regression analysis of all bulk and rhizosphere samples showed a significant correlation of the relative abundance of intI1 and korB genes, supporting this assumption. However, in the rhizosphere samples the relative abundance of korB genes in the three soils was significantly higher than most of the class 1 integron components (Figure 1), indicating also a high prevalence of IncP-1 plasmids not carrying class 1 integrons. Plasmids of the IncP- $1 \varepsilon$ subgroup, which were captured from manure and manured soil were only detected in two of the four replicates of LL rhizosphere (data not shown) indicating only a minor contribution of this subgroup in the distribution of class 1 integrons in the soils which did not receive manure in the last 10 years. This is in line with the results reported by Heuer et al. (2012) who detected only a very low abundance of IncP-1 $1 \varepsilon$ plasmids in arable soils. However, they could show that the application of manure spiked with the antibiotic sulfadiazine increased the relative abundance of IncP$1 \varepsilon$ plasmids, which might be related to co-selection of class 1 integrons with the sull resistance gene located on these plasmids.

\section{CONCLUDING REMARKS}

In summary, this study provided insights into the occurrence of class 1 integron components in previously not studied environments such as on-farm biopurification systems, digestates, and soils treated or untreated with manure. The high prevalence of class 1 integron components in samples from manured soils, on-farm pesticide biopurification systems and digestates was not unexpected considering the use of piggery manure in all these settings. However, the detection of class 1 integron components in soils which for at least 10 years were only fertilized with minerals and the enrichment of class 1 integrons and IncP-1 plasmids carrying bacteria in the rhizosphere which most likely was a response to root exudation were striking findings of the present study. The quantification of IncP-1 plasmids revealed a potential association with class 1 integrons in bulk soil, while in the rhizosphere of lettuce the relative abundance of IncP-1 plasmids was much higher than the abundance of class 1 integrons. Plasmids of the IncP-1ع subgroup previously identified as important vectors of antibiotic resistance genes in manure and manured soil, likely had a small contribution to the presence of class 1 integrons in the investigated arable soil which did not receive manure for at least 10 years. The observed high prevalence of intI1 and $q a c E \Delta 1$ genes in the environment and their potential localization on broad host range plasmids may represent a constant reservoir for the spread of these genes into hospitals, food industry, or other man-made environments where QACs are used for biocidal purposes, which may lead to a co-selection of class 1 integrons and associated antibiotic resistance genes. Exogenous isolation of IncP-1 plasmids from the rhizosphere of lettuce will be required to confirm the localization of qacE $\Delta 1$ and the environmental factors which likely triggered the increased abundance of IncP-1 plasmid carrying bacteria in the rhizosphere of lettuce.

\section{ACKNOWLEDGMENTS}

Sven Jechalke and Holger Heuer were funded by the Deutsche Forschungsgemeinschaft (DFG) in the framework of the Research Unit FOR 566 "Veterinary medicines in soil: Basic research for risk analysis" (SM59/5-3). Susanne Schreiter was funded by the DFG in the framework of the project "Key factors influencing fate and activity of bacterial inoculants and their effect on the indigenous microbial community in the rhizosphere" (SM59/111). Birgit Wolters was funded by the German Federal Ministry of Food, Agriculture and Consumer Protection through the Federal Office for Agriculture and Food, Bonn, Germany (grant number 2810HS032). Simone Dealtry was funded by the EU project METAEXPLORE "Metagenomics for bioexploration-Tools and application." We thank Vincent Dunon and Dirk Springael for their contribution and suggestion to analyze the mobilome of the biofilters, Rita Grosch for her contribution in conducting and maintaining of the experimental unit in Grossbeeren, and Robert Kreuzig for his contribution to provide samples from biogas plants. We thank Ilse-Marie Jungkurth for proofreading the manuscript.

\section{SUPPLEMENTARY MATERIAL}

The Supplementary Material for this article can be found online at: http://www.frontiersin.org/journal/10.3389/fmicb.2013. 00420/abstract

Figure S1 | PCR amplification from total community DNA and subsequent Southern blot hybridization of class 1 integron integrase gene intl1.

Figure S2 | PCR amplification from total community DNA and subsequent Southern blot hybridization of quaternary ammonium compound resistance gene qacE.

Figure S3 | PCR amplification from total community DNA and subsequent Southern blot hybridization of quaternary ammonium compound resistance gene qacE 1.

Figure S4 | PCR amplification from total community DNA and subsequent Southern blot hybridization of class 1 integron integrase gene intl1.

Figure S5 | PCR amplification from total community DNA and subsequent Southern blot hybridization of quaternary ammonium compound resistance gene qacE 1.

\section{REFERENCES}

Bahl, M. I., Burmølle, M., Meisner, A., Hansen, L. H., and Sørensen, S. J. (2009). All IncP-1 plasmid subgroups, including the novel $\varepsilon$ subgroup, are prevalent in the influent of a Danish wastewater treatment plant. Plasmid 62, 134-139. doi: 10.1016/j.plasmid.2009.05.004

Barraud, O., Baclet, M. C., Denis, F., and Ploy, M. C. (2010). Quantitative multiplex real-time PCR for detecting class 1, 2 and 3 integrons. J. Antimicrob. Chemother. 65, 1642-1645. doi: 10.1093/jac/dkq167

Berg, G., and Smalla, K. (2009). Plant species and soil type cooperatively shape the structure and function of microbial communities in the rhizosphere. FEMS Microbiol. Ecol. 68, 1-13. doi: 10.1111/j.1574-6941.2009. 00654.x 
Betteridge, T., Partridge, S. R., Iredell, J. R., and Stokes, H. W. (2011). Genetic context and structural diversity of class 1 integrons from human commensal bacteria in a hospital intensive care unit. Antimicrob. Agents Chemother. 55, 3939-3943. doi: 10.1128/AAC.01831-10

Buffet-Bataillon, S., Tattevin, P., Bonnaure-Mallet, M., and Jolivet-Gougeon, A. (2012). Emergence of resistance to antibacterial agents: the role of quaternary ammonium compounds-a critical review. Int. J. Antimicrob. Agents 39, 381-389. doi: 10.1016/j.ijantimicag.2012.01.011

Chuanchuen, R., Khemtong, S., and Padungtod, P. (2007). Occurrence of $q a c E / q a c E \Delta 1$ genes and their correlation with class 1 integrons in Salmonella enterica isolates from poultry and swine. Southeast Asian J. Trop. Med. Public Health 38, 855-862.

Farkas, A., Butiuc-Keul, A., Ciataras, D., Neamtu, C., Craciunas, C., Podar, D., et al. (2013). Microbiological contamination and resistance genes in biofilms occurring during the drinking water treatment process. Sci. Total Environ. 443, 932-938. doi: 10.1016/j.scitotenv.2012.11.068

Gaze, W. H., Abdouslam, N., Hawkey, P. M., and Wellington, E. M. H. (2005). Incidence of class 1 integrons in a quaternary ammonium compoundpolluted environment. Antimicrob. Agents Chemother. 49, 1802-1807. doi: 10.1128/AAC.49.5.1802-1807.2005

Gaze, W. H., Zhang, L. H., Abdouslam, N. A., Hawkey, P. M., Calvo-Bado, L., Royle, J., et al. (2011). Impacts of anthropogenic activity on the ecology of class 1 integrons and integron-associated genes in the environment. ISME J. 5, 1253-1261. doi: 10.1038/ismej.2011.15

Gilbert, P., and Moore, L. E. (2005). Cationic antiseptics: diversity of action under a common epithet. J. Appl. Microbiol. 99, 703-715. doi: 10.1111/j.13652672.2005.02664.x

Gillings, M. R., Krishnan, S., Worden, P. J., and Hardwick, S. A. (2008). Recovery of diverse genes for class 1 integron-integrases from environmental DNA samples. FEMS Microbiol. Lett. 287, 56-62. doi: 10.1111/j.1574-6968.2008.01291.x

Gillings, M. R., Xuejun, D., Hardwick, S. A., Holley, M. P., and Stokes, H. W. (2009). Gene cassettes encoding resistance to quaternary ammonium compounds: a role in the origin of clinical class 1 integrons? ISME J. 3, 209-215. doi: 10.1038 /ismej. 2008.98

Heuer, H., Binh, C. T. T., Jechalke, S., Kopmann, C., Zimmerling, U., Krögerrecklenfort, E., et al. (2012). IncP-1e plasmids are important vectors of antibiotic resistance genes in agricultural systems: diversification driven by class 1 integron gene cassettes. Front. Microbiol. 3:2. doi: 10.3389/fmicb. 2012.00002

Heuer, H., and Smalla, K. (2012). Plasmids foster diversification and adaptation of bacterial populations in soil. FEMS Microbiol. Rev. 36, 1083-1104. doi 10.1111/j.1574-6976.2012.00337.x

Holah, J. T., Taylor, J. H., Dawson, D. J., and Hall, K. E. (2002). Biocide use in the food industry and the disinfectant resistance of persistent strains of Listeria monocytogenes and Escherichia coli. J. Appl. Microbiol. 92, 111S-120S. doi: 10.1046/j.1365-2672.92.5s1.18.x

Ioannou, C. J., Hanlon, G. W., and Denyer, S. P. (2007). Action of disinfectant quaternary ammonium compounds against Staphylococcus aureus. Antimicrob. Agents Chemother. 51, 296-306. doi: 10.1128/AAC.00375-06

Jaglic, Z., and Cervinkova, D. (2012). Genetic basis of resistance to quaternary ammonium compounds - the qac genes and their role: a review. Vet. Med. (Praha) 57, 275-281.

Jechalke, S., Dealtry, S., Smalla, K., and Heuer, H. (2013a). Quantification of IncP1 plasmid prevalence in environmental samples. Appl. Environ. Microbiol. 79, 1410-1413. doi: 10.1128/AEM.03728-12

Jechalke, S., Focks, A., Rosendahl, I., Groeneweg, J., Siemens, J., Heuer, H., et al. (2013b). Structural and functional response of the soil bacterial community to application of manure from difloxacin-treated pigs. FEMS Microbiol. Ecol. 87, 78-88. doi: 10.1111/1574-6941.12191

Jechalke, S., Kopmann, C., Rosendahl, I., Groeneweg, J., Weichelt, V., Krögerrecklenfort, E., et al. (2013c). Increased abundance and transferability of resistance genes after field application of manure from sulfadiazine-treated pigs. Appl. Environ. Microbiol. 79, 1704-1711. doi: 10.1128/AEM.03172-12

Kazama, H., Hamashima, H., Sasatsu, M., and Arai, T. (1998). Distribution of the antiseptic-resistance genes $q a c E$ and $q a c E \Delta 1$ in Gram-negative bacteria. FEMS Microbiol. Lett. 159, 173-178. doi: 10.1016/S0378-1097(97)00563-6

Kim, D. U., Kim, M. S., Lim, J. S., and Ka, J. O. (2013). Widespread occurrence of the $t f d-I I$ genes in soil bacteria revealed by nucleotide sequence analysis of 2,4-dichlorophenoxyacetic acid degradative plasmids pDB1 and p712. Plasmid 69, 243-248. doi: 10.1016/j.plasmid.2013.01.003
Król, J. E., Penrod, J. T., McCaslin, H., Rogers, L. M., Yano, H., Stancik, A. D., et al. (2012). Role of IncP-1beta plasmids pWDL7::rfp and pNB8c in chloroaniline catabolism as determined by genomic and functional analyses. Appl. Environ. Microbiol. 78, 828-838. doi: 10.1128/AEM.07480-11

Kücken, D., Feucht, H., and Kaulfers, P. (2000). Association of qacE and qacE $\Delta 1$ with multiple resistance to antibiotics and antiseptics in clinical isolates of Gram-negative bacteria. FEMS Microbiol. Lett. 183, 95-98. doi: 10.1016/S03781097(99)00636-9

Mazel, D. (2006). Integrons: agents of bacterial evolution. Nat. Rev. Microbiol. 4, 608-620. doi: 10.1038/nrmicro1462

Mølbak, L., Molin, S., and Kroer, N. (2007). Root growth and exudate production define the frequency of horizontal plasmid transfer in the rhizosphere. FEMS Microbiol. Ecol. 59, 167-176. doi: 10.1111/j.1574-6941.2006.00229.x

Morente, E. O., Fernandez-Fuentes, M. A., Burgos, M. J. G., Abriouel, H., Pulido, R. P., and Galvez, A. (2013). Biocide tolerance in bacteria. Int. J. Food Microbiol. 162, 13-25. doi: 10.1016/j.ijfoodmicro.2012.12.028

Moura, A., Henriques, I., Ribeiro, R., and Correia, A. (2007). Prevalence and characterization of integrons from bacteria isolated from a slaughterhouse wastewater treatment plant. J. Antimicrob. Chemother. 60, 1243-1250. doi: $10.1093 / \mathrm{jac} / \mathrm{dkm} 340$

Oliveira, C. S., Lazaro, B., Azevedo, J. S. N., Henriques, I., Almeida, A., and Correia, A. (2012). New molecular variants of epsilon and beta IncP1 plasmids are present in estuarine waters. Plasmid 67, 252-258. doi: 10.1016/j.plasmid.2011.11.002

Partridge, S. R., Tsafnat, G., Coiera, E., and Iredell, J. R. (2009). Gene cassettes and cassette arrays in mobile resistance integrons. FEMS Microbiol. Rev. 33, 757-784. doi: 10.1111/j.1574-6976.2009.00175.x

Popowska, M., and Krawczyk-Balska, A. (2013). Broad-host-range IncP1 plasmids and their resistance potential. Front. Microbiol. 4:44. doi: 10.3389/fmicb.2013.00044

Pukall, R., Tschäpe, H., and Smalla, K. (1996). Monitoring the spread of broad host and narrow host range plasmids in soil microcosms. FEMS Microbiol. Ecol. 20, 53-66. doi: 10.1111/j.1574-6941.1996.tb00304.x

Rühlmann, J. (2006). The box plot experiment in Grossbeeren after six rotations: effect of fertilization on crop yield. Arch. Agron. Soil Sci. 52, 313-319. doi: 10.1080/03650340600638701

Rühlmann, J., and Ruppel, S. (2005). Effects of organic amendments on soil carbon content and microbial biomass - results of the long-term box plot experiment in Grossbeeren. Arch. Agron. Soil Sci. 51, 163-170. doi: $10.1080 / 03650340400026651$

Sambrook, J., Fritsch, E. F., and Maniatis, T. (1989). Molecular Cloning: A Laboratory Manual. Cold Spring Harbor, NY: Cold Spring Harbor Laboratory Press.

Sandvang, D., Aarestrup, F. M., and Jensen, L. B. (1997). Characterisation of integrons and antibiotic resistance genes in Danish multiresistant Salmonella enterica Typhimurium DT104. FEMS Microbiol. Lett. 157, 177-181. doi: 10.1111/j.1574-6968.1997.tb12770.x

Schlüter, A., Szczepanowski, R., Pühler, A., and Top, E. M. (2007). Genomics of IncP-1 antibiotic resistance plasmids isolated from wastewater treatment plants provides evidence for a widely accessible drug resistance gene pool. FEMS Microbiol. Rev. 31, 449-477. doi: 10.1111/j.1574-6976.2007. 00074.x

Sen, D., Van der Auwera, G. A., Rogers, L. M., Thomas, C. M., Brown, C. J., and Top, E. M. (2011). Broad-host-range plasmids from agricultural soils have IncP-1 backbones with diverse accessory genes. Appl. Environ. Microbiol. 77, 7975-7983. doi: 10.1128/AEM.05439-11

Stalder, T., Barraud, O., Casellas, M., Dagot, C., and Ploy, M.-C. (2012). Integron involvement in environmental spread of antibiotic resistance. Front. Microbiol. 3:119. doi: 10.3389/fmicb.2012.00119

Stalder, T., Barraud, O., Jové, T., Casellas, M., Gaschet, M., Dagot, C., et al. (2013). Quantitative and qualitative impact of hospital effluent on dissemination of the integron pool. ISME J. doi: 10.1038/ismej.2013.189. [Epub ahead of print].

Suzuki, M. T., Taylor, L. T., and DeLong, E. F. (2000). Quantitative analysis of small-subunit rRNA genes in mixed microbial populations via $5^{\prime}$-nuclease assays. Appl. Environ. Microbiol. 66, 4605-4614. doi: 10.1128/AEM.66.11.46054614.2000

Top, E. M., and Springael, D. (2003). The role of mobile genetic elements in bacterial adaptation to xenobiotic organic compounds. Curr. Opin. Biotechnol. 14, 262-269. doi: 10.1016/S0958-1669(03)00066-1 
van Elsas, J. D., Turner, S., and Bailey, M. J. (2003). Horizontal gene transfer in the phytosphere. New Phytol. 157, 525-537. doi: 10.1046/j.1469-8137.2003.00697.x

Yano, H., Rogers, L. M., Knox, M. G., Heuer, H., Smalla, K., Brown, C. J., et al. (2013). Host range diversification within the IncP-1 plasmid group. Microbiology 159, 2303-2315. doi: 10.1099/mic.0.068387-0

Zhao, W. H., Chen, G. L., Ito, R., Kimura, S., and Hu, Z. Q. (2012). Identification of a plasmid-borne bla(IMP-11) gene in clinical isolates of Escherichia coli and Klebsiella pneumoniae. J. Med. Microbiol. 61, 246-251. doi: 10.1099/jmm.0. 035626-0

Conflict of Interest Statement: The authors declare that the research was conducted in the absence of any commercial or financial relationships that could be construed as a potential conflict of interest.
Received: 01 October 2013; accepted: 20 December 2013; published online: 17 January 2014.

Citation: Jechalke S, Schreiter S, Wolters B, Dealtry S, Heuer H and Smalla K (2014) Widespread dissemination of class 1 integron components in soils and related ecosystems as revealed by cultivation-independent analysis. Front. Microbiol. 4:420. doi: 10.3389/fmicb.2013.00420

This article was submitted to Antimicrobials, Resistance and Chemotherapy, a section of the journal Frontiers in Microbiology.

Copyright (C) 2014 Jechalke, Schreiter, Wolters, Dealtry, Heuer and Smalla. This is an open-access article distributed under the terms of the Creative Commons Attribution License (CC BY). The use, distribution or reproduction in other forums is permitted, provided the original author(s) or licensor are credited and that the original publication in this journal is cited, in accordance with accepted academic practice. No use, distribution or reproduction is permitted which does not comply with these terms. 